\title{
Versão simplificada
}

Título do projeto: Desenvolvimento de uma vacina de subunidade contra a leptospirose.

\section{Resumo:}

A leptospirose é uma zoonose reemergente de grande impacto na saúde animal e pública, que tem como agente etiológico às espécies patogênicas do gênero Leptospira. As vacinas comerciais contra esta doença são preparações de culturas de leptospiras de sorovares patogênicos, inativadas pela ação do calor ou formol (bacterinas). Estas vacinas são sorovar específicas e estimulam predominantemente a resposta imune humoral, reforçando a necessidade de revacinação anual para manter os níveis de anticorpos protetores. Além disso, há controvérsias sobre este tipo de vacina em relação à inibição da colonização renal. Por isso, novos antígenos têm sido avaliados para compor uma vacina mais eficaz contra a leptospirose, que confira proteção contra as diversas espécies patogênicas, previna a colonização bacteriana, gere resposta imune duradoura e apresente mínimos efeitos adversos. Os candidatos vacinais mais promissores são as proteínas de superfície LigA e LigB (Leptospiral immunoglobulin-like proteins), que são expressas durante a infecção e participam dos mecanismos de adesão às células do hospedeiro. Outra proteína promissora é a LcpA (Leptospiral complement regulator-acquiring protein A), cuja função é a interação com o fator regulador C4BP, sugerindo uma estratégia das leptospiras de evasão do sistema complemento. LcpA é conservada entre as espécies patogênicas e expressa durante o curso da infecção, sugerindo um papel potencial como antígeno vacinal. Assim, o objetivo geral deste trabalho foi desenvolver uma vacina de subunidade contra a leptospirose utilizando as proteínas recombinantes LigAC (porção C-terminal da proteína LigA) e a proteína LcpA como antígenos. Com o intuito de aumentar a imunogenicidade destas proteínas, através do melhoramento da eficiência dos mecanismos de captura, processamento e apresentação do antígeno ao sistema imune, foram utilizadas duas estratégias vacinais. A primeira consistiu na fusão das proteínas ao domínio $\mathrm{ZZ}$ da proteína $\mathrm{A}$ de Staphylococcus aureus, capaz de se ligar à região Fc das imunoglobulinas; e ao domínio $R$ da toxina diftérica (DTR), um ligante à heparam sulfato. A segunda estratégia consistiu na utilização de três 
adjuvantes: hidróxido de alumínio (Alum), CpG-ODN (agonista de TLR-9) e o anticorpo monoclonal anti-MHC II (clone 14.4.4S). Os resultados obtidos mostraram que a formulação vacinal contendo a proteína LcpA fusionada aos domínios ZZ e DTR mais Alum foi capaz de induzir 100\% e 60\% de proteção contra a morte nos desafios homólogo e heterólogo, respectivamente. A proteína LcpA não fusionada induziu proteção parcial $(60 \%)$ na presença de Alum. Estes resultados sugerem que os domínios ZZ e DTR são capazes de apresentar o antígeno de maneira mais eficiente. As formulações vacinais contendo LigAC e LcpA fusionadas aos domínios, independente do adjuvante utilizado, foram capazes de induzir proteção contra a morte, mas não foram capazes de inibir a colonização renal, apesar dos altos títulos de anticorpos, direcionados principalmente à proteína LigAC. Assim, conclui-se que as proteínas LigAC e LcpA fusionadas aos domínios ZZ e DTR são candidatos vacinais promissores; e que outras estratégias vacinais utilizando essas proteínas precisam ser testadas para melhorar a imunogenicidade das mesmas e conseguir imunidade esterilizante contra a leptospirose.

Palavras-chave: Leptospira, Leptospirose, LigA, LcpA, Vacina de subunidade.

\section{Abstract:}

Leptospirosis is a reemerging zoonosis of great impact in animal and public health, which has the pathogenic species of genus Leptospira as its etiological agent. Commercial vaccines against this disease consist of leptospiral culture preparations from pathogenic serovars, inactivated by heat or formaldehyde (bacterins). These vaccines are serovar specific and stimulate predominantly humoral immune response, reinforcing the need for annual revaccination to maintain the protective antibody levels. Moreover, there is controversy about these type of vaccines regarding inhibition of renal colonization and bacterial dissemination. Thus, new antigens have been evaluated to compose an effective vaccine against leptospirosis that confers protection against different pathogenic species, prevents bacterial colonization, generates long-lasting immune responses, and exhibits minimum adverse effects. The most promising vaccine candidates are surface proteins LigA and LigB (Leptospiral immunoglobulin-like), which are expressed during infection and play a role in the mechanisms of adhesion to the host cells. Another promising protein is LcpA (Leptospira 
complement regulator-acquiring protein), which interacts with the regulator factor C4BP, suggesting leptospires' strategy for evading the complement system. LcpA is conserved among pathogenic species and expressed during infection, suggesting a potential role as a vaccine antigen. Therefore, this work aimed to develop a subunit vaccine against leptospirosis, using recombinant leptospiral proteins LigAC (C-terminal region of protein $\operatorname{LigA}$ ) and LcpA, as antigens. Two strategies were used for increasing the immunogenicity of these proteins, through improvement of the efficiency of antigen capture, processing, and presentation to the immune systems mechanisms. The first consisted of fusion of proteins to domain ZZ of protein A of Staphylococcus aureus, capable of binding to the Fc region of immunoglobulins; and to $R$ domain of diphtheria toxin (DTR), which is a ligand of heparan sulfate. The second strategy consisted of testing three adjuvants: aluminium hydroxide (Alum), CpG-ODN and monoclonal antibody anti-MHC II (14.4.4S). Results obtained showed that the vaccine formulation containing LcpA protein fused to domains ZZ and DTR plus Alum was capable of inducing $100 \%$ and $60 \%$ of protection against death in both homologous and heterologous challenge, respectively. Protein LcpA not fused induced partial protection $(60 \%)$ in presence of Alum. These results suggest that domains $Z Z$ and DTR are capable of presenting antigens in a much efficient manner. Vaccine formulations consisting of LigAC and LCpA fused to domains, independently of the adjuvant used, were able to induce protection against death caused by leptospirosis in hamsters, but they were not capable of inhibiting renal colonization, despite the high antibody titers directed to the LigAC protein. Thus, it can be concluded that proteins LigAC and LcpA fused to domains ZZ and DTR are promising vaccine candidates; and that other vaccines strategies, using these proteins need to be tested to enhance their immunogenicity and achieve sterilizing immunity agains leptospirosis.

Keywords: Leptospira, leptospirosis, LigA, LcpA, subunit vaccine 